\title{
Semen quality of male partners of infertile couples living with HIV infection
}

\section{Oliver Chukwujekwu Ezechi*, Agatha Eilleen Wapmuk, Aigbe Greg Ohihoin, Innocent Achanya Otobo Ujah}

Department of Clinical Sciences, Nigerian Institute of Medical Research Lagos, Nigeria

Received: 21 March 2016

Accepted: 15 March 2016

\author{
*Correspondence: \\ Dr. Oliver Chukwujekwu Ezechi, \\ E-mail: oezechi@yahoo.co.uk
}

Copyright: (c) the author(s), publisher and licensee Medip Academy. This is an open-access article distributed under the terms of the Creative Commons Attribution Non-Commercial License, which permits unrestricted non-commercial use, distribution, and reproduction in any medium, provided the original work is properly cited.

\begin{abstract}
Background: Infertility among HIV positive couples are increasingly been reported in various gynaecology clinic. Unfortunately research into aetiology of infertility is out tune with this emerging trend. This study was conducted to determine the semen quality among infertile HIV positive couples.

Methods: A retrospective analysis of information obtained during routine care of infertile HIV positive couple at a large HIV treatment in Lagos Nigeria.

Results: Over thirty percent $(31.7 \%)$ of the male partners of HIV positive couple in study had abnormal semen quality. Secondary infertility was the commonest (79.2\%). The quality of semen of the HIV negative men in the study was significantly better compared to that of HIV positive men $(\mathrm{p}<0.001)$. Of the five semen parameters compared, HIV positive participants with more severe diseases had significantly lower mean sperm volume $(p=0.003)$, sperm concentration $(\mathrm{p}=0.0002)$ and total sperm concentration $(\mathrm{p}<0.001)$ compared to of HIV positive participants with less severe diseases . Approximately $22 \%$ of the semen of the men in this study was infected, with Staph aureus, E coli and Klebsiella being the most common microbial isolates.

Conclusions: Male factor contributes about one third of infertility in this study and severity of HIV diseases impacts on semen quality. Further studies are needed to evaluate if antiretroviral therapy will reverse the effect of HIV infection on semen quality.
\end{abstract}

Keywords: Men, Infertility, Semen, Spermatozoa, HIV, Couple

\section{INTRODUCTION}

HIV/AIDS epidemic has emerged as one of the major challenges for the world, going from a relatively small problem in the 1980 s to one of the leading causes of mortality in the 1990s. ${ }^{1}$ Most of the persons infected reside in sub-Saharan Africa, with women accounting for over $50 \%$ of cases. In addition, majority of those infected are within the reproductive age group. ${ }^{2}$ As a result of the very high morbidity and mortality associated with HIV infection then, fertility issues were relegated to the background as the major thrust was to reduce mortality and transmission of Infections. ${ }^{3}$
In the last decade, the grin picture has changed as the development and introduction of highly active antiretroviral therapy (HAART) has transformed the prognosis for HIV-infected individuals. The resultant increased longevity and quality of life has caused an increasing number of reproductive-age heterosexual HIV positive couples desiring to have children. ${ }^{4}$

Infertility among HIV positive couples are increasingly been reported, but unfortunately there are limited references, standard values and rates for the interpretation of results and comparison. ${ }^{5}$

Nigerian falls within both the infertility belt and HIV high burden setting of sub-Saharan and thus expected to 
also have high infertility burden among HIV positive persons. ${ }^{6}$ From extensive literature search, there paucity of information on infertility among HIV positive couple. This study was therefore conducted to determine the pattern of anomalies in the semen of male partners in HIV positive couples, aimed at establishing the contribution of male factors to infertility among HIV positive couples in our environment.

\section{METHODS}

\section{Study design and setting}

This is a retrospective review of data obtained in the management of HIV positive couples referred for the management of infertility at the gynaecology clinic over a 10 year period (January 2004-December 2013).

The study setting was the Gynaecologic clinic, Clinical sciences Division, Nigerian Institute of Medical Research, Lagos. The division also host a large HIV treatment centre that started operations in 2002 from where the HIV positive couples are referred to the clinic. The centre currently provides comprehensive, HIV care, treatment and support for over 23,000 HIV positive patients. Sixty five percent of the patients come from Lagos and the rest from the other 5 states of south west Nigeria, as well as from north-central, south-south and south-eastern Nigeria. A little over $0.03 \%$ comes from the neighbouring West African countries. Patients are

\section{Study population}

Participants in this study were infertile couples referred to the gynaecology clinic from the HIV treatment clinic, specialist clinics, clinical diagnostic laboratory, NIMR and other private and public laboratory and clinics outside the Institute.

\section{Investigation of male Infertility at the gynaecology clinic}

The diagnosis of male fertility is dependent on the findings of seminal fluid analysis, hormonal investigation and microbiological assessment. Further investigations are based on the outcome of the basic test. Simultaneous we assessed the female partner, even if abnormalities are found in the male since both partner could have problem.

Semen samples are collected and processed according to WHO standard Semen sample collections is performed following abstinence from ejaculation for 3-5 days and transported to the laboratory within less than 1 hour of production while maintaining sample at body temperature. ${ }^{7}$ Samples were collected using masturbation only into sterile screw capped plastic universal containers. Using WHO standard semen analysis was carried out at the clinical diagnostic laboratory by determining semen liquefaction, volume, appearance, $\mathrm{pH}$, sperm concentration, motility, morphology, viability, and the presence of WBC or RBC. Each semen sample is cultured in appropriate culture media at $37^{\circ} \mathrm{C}$ for $24-48$ hours to detect any associated bacterial pathogens. ${ }^{7}$ Positive samples are sub-cultured to determine the sensitivity pattern to antimicrobial agents. If values are normal according to WHO criteria, one test

Suffices, however If the results are abnormal, semen analysis is repeated.

Hormonal screening are limited to determining follicle stimulating hormone (FSH), luteinising hormone (LH), and testosterone levels in case of abnormal semen parameters. Further hormonal test are dependent on the outcome of these initial tests.

\section{Data management}

Relevant information was collected from the case records and laboratory results of the patients using a Proforma designed for the study. Information obtained includes sociodemographic characteristics, medical, reproductive and HIV treatment history and the results of infertility investigations. The cause of infertility in the partner was also obtained. The obtained information is transferred into an electronic database designed by trained data entry clerks. The entered data was further reviewed against the proforma to avoid transcription error. SPSS for windows version 20.0 statistical package was used to analyse the data. Results are reported as frequencies and mean, with level of significant set at less than $0.05(P<0.05)$.

\section{RESULTS}

A total of 419 infertile HIV positive couple were investigated during the study period, of which majority have serodiscordant HIV status with male negative (221; $52.7 \%$ ) and HIV serocordance with both partners positive in the remaining $198(47.3 \%)$ cases. The infertility was of secondary type in the majority of couples $(332 ; 79.2 \%)$. The remaining where cases of primary infertility (87; $20.7 \%$ ).

\section{Sociodemographic and HIV related characteristics of patients}

The sociodemographic characteristics of the male partners of the HIV positive couple is shown in table 1 . Their ages ranged from 27 to 67 with a mean of 42.4 (SD: 10.5$)$ years. Over two-third of the patients $(68.2 \%)$ were 40 years and above. Majority of the patients were gainfully employed $(341 ; 81.4 \%)$, married $(395 ; 94.3 \%)$ and had at least a secondary education $(334 ; 79.7 \%)$. There were no statistically significant difference between the sociodemographic of the HIV positive and negative male partners $(\mathrm{P}>0.05)$.

The HIV related characteristics of 198 HIV positive patients in the study are presented in Table 2. The CD4 cell count ranged from 106 to 613 cells/mm3 with a mean 
of $421.7 \pm 1691$. The majority $144(72.7 \%)$ of the HIV positive men had CD 4 cells counts below 500 cells $/ \mathrm{mm} 3$ and were already on antiretroviral therapy $(122 ; 61.6 \%)$. While $80(40.4 \%)$ had HIV viral load of less than 1000 copies, $122(61.6 \%)$ women were on highly active antiretroviral therapy (HAART) at the time of first contact at the gynaecology clinic.

Table 1: Sociodemographic characteristics of the male partner of the HIV positive couples presenting with infertility.

\begin{tabular}{|c|c|c|c|c|}
\hline \multirow[b]{2}{*}{ Characteristics } & \multicolumn{4}{|c|}{$\begin{array}{l}\text { Number of male partners of the infertile } \\
\text { couples }\end{array}$} \\
\hline & $\begin{array}{l}\text { ALL } \\
\mathrm{n}=419 \\
(\%)\end{array}$ & $\begin{array}{l}\text { HIV } \\
\text { positive } \\
\mathrm{n}=198 \\
(\%)\end{array}$ & $\begin{array}{l}\text { HIV } \\
\text { negative } \\
\mathrm{n}=221 \\
(\%)\end{array}$ & $\begin{array}{l}P \\
\text { value }\end{array}$ \\
\hline \multicolumn{5}{|l|}{ Age (years) } \\
\hline$<30$ & $19(4.5)$ & $6(3.0)$ & $11(5.0)$ & \\
\hline $30-39$ & $114(27.2)$ & $57(28.8)$ & $57(25.7)$ & \\
\hline $40-49$ & $205(48.9)$ & $89(44.9)$ & $106(48.0)$ & \\
\hline$\geq 50$ & $81(19.3)$ & $46(23.2)$ & $47(21.3)$ & \\
\hline Range & $27-67$ & $29-67$ & $27-59$ & \\
\hline Mean(SD) & $42.4(10.5)$ & $43.9(9.1)$ & $43.2(7.9)$ & 0.25 \\
\hline \multicolumn{5}{|l|}{$\begin{array}{l}\text { Marital } \\
\text { status }\end{array}$} \\
\hline Married & $395(94.3)$ & 186(93.9) & $209(94.6)$ & 0.23 \\
\hline Single & - & - & - & \\
\hline $\begin{array}{l}\text { Co-habiting } \\
\text { Work status }\end{array}$ & \multicolumn{3}{|c|}{ Work status } & 0.78 \\
\hline Working & $341(81.4)$ & $159(80.3)$ & 181(81.9) & 0.68 \\
\hline Not working & $78(18.6)$ & $39(19.7)$ & $40((18.1)$ & 0.78 \\
\hline \multicolumn{5}{|l|}{$\begin{array}{l}\text { Educational } \\
\text { status }\end{array}$} \\
\hline$<$ Secondary & $85(20.3)$ & $39(19.7)$ & $46(20.8)$ & \\
\hline$\geq$ Secondary & $334(79.7)$ & $159(80.3)$ & $175(79.2)$ & \\
\hline
\end{tabular}

\section{Semen parameters of patients}

The seminal fluid volume ranged from $0.5 \mathrm{mls}$ to $7.5 \mathrm{mls}$ with a mean of $3.8 \pm 2.3 \mathrm{mls}$. The mean seminal fluid volume of $3.9 \pm 2.5 \mathrm{mls}$ among the HIV negative male partners group was higher than a mean of $2.9 \pm \mathrm{mls}$ among the HIV positive male partner group $(\mathrm{P}<0.001)$. The semen concentration ranged $0-152.5 \times 10^{6}$, with a mean of $83.1 \pm 11.4 \times 10^{6}$. The mean sperm concentration of $97.3 \pm 9.5 \times 10^{6}$ among the HIV negative male partners group was significantly higher $(\mathrm{p}<0.001)$ than $76.3 \pm 12.1$ $\times 10^{6}$ among the HIV positive male partners. The mean total sperm count of the male patients ranged from 0 to $744.8 \times 10^{6}$ with a mean of $315.4 \times 10^{6}$. The mean total sperm count of $379.5 \pm 49.1 \times 10^{6}$ among the male HIV negative group was also significantly higher than the mean of $201.3 \pm 62.1 \times 10^{6}$ among the male HIV positive group $(\mathrm{p}=0.0002)$.

The pattern of semen density of the male partners of infertile HIV positive couple is shown in table 3. Of the 419 male patients in the study, majority had normospermia $(286 ; 68.3 \%)$ and the remaining 157 men had oligozoospermia $(126 ; 30.1 \%)$ or azoospermia
$(17 ; 1.7 \%)$. The proportion of individuals with abnormal sperm density was significantly higher in the HIV positive men $(38.4 \%)$ compared to $25.8 \%$ in the HIV negative men $(\mathrm{P}<0.039)$.

Table 2: HIV related history and laboratory characteristics of the $198 \mathrm{HIV}$ positive male in the study.

\begin{tabular}{|ll|}
\hline Characteristics & Number of patients (\%) \\
\hline CD4 cell count & \\
$<500$ & $144(72.7)$ \\
$\geq 500$ & $54(27.3)$ \\
Range & $106-613$ \\
Mean(SD) & $421.7(169.1)$ \\
Viral load & \\
$<\quad 1,000$ & $80(40.4)$ \\
$1,000-100,000$ & $64(32.3)$ \\
$\geq 100,000$ & $54(27.3)$ \\
HIV treatment status & \\
On treatment & $122(61.6)$ \\
Not on treatment & $76(38.4)$ \\
\hline
\end{tabular}

Table 3: The pattern of semen density of the male partners of infertile HIV positive couples in the study.

\begin{tabular}{|c|c|c|c|c|}
\hline Sperm density & $\begin{array}{l}\text { All } \\
\mathrm{n}= \\
419 \\
(\%)\end{array}$ & $\begin{array}{l}\text { HIV } \\
\text { positives } \\
\mathbf{n}=198 \\
(\%)\end{array}$ & $\begin{array}{l}\text { HIV } \\
\text { negatives } \\
\mathbf{n}=221 \\
(\%)\end{array}$ & Remarks \\
\hline Normospermia & $\begin{array}{l}286 \\
(68.3)\end{array}$ & $\begin{array}{l}122 \\
(61.6)\end{array}$ & $\begin{array}{l}164 \\
(74.2)\end{array}$ & \multirow{3}{*}{$\begin{array}{l}\text { OR: } 1.5 \\
95 \% \text { CI: } \\
1.0-2.3 \\
P=0.039\end{array}$} \\
\hline Oligozospermia & $\begin{array}{l}126 \\
(30.1)\end{array}$ & $\begin{array}{l}70 \\
(35.4)\end{array}$ & $\begin{array}{l}56 \\
(25.3)\end{array}$ & \\
\hline Azospermia & $\begin{array}{l}17 \\
(1.7)\end{array}$ & $\begin{array}{l}6 \\
(3.0)\end{array}$ & $\begin{array}{l}11 \\
(0.5)\end{array}$ & \\
\hline
\end{tabular}

The other common semen abnormalities observed among the patients were morphological abnormalities of teratozoospermia $(97 ; 23.2 \%)$ and asthenozoospermia $(56 ; 13.4 \%)$. A larger percentage of men in the HIV positive groups $(34.3 \% ; 68)$ have morphological abnormalities compared to $19.7 \%$ (44) in their HIV negative counterparts ( $\mathrm{p}=0.001$; OR:2.2;95\% CI:1.4-3.4). Multiple abnormalities of oligoteratozoospermia (19;4.5\%), asthenoteratozoospermia (16;3.8), oligoasthenozoospermia $(13 ; 3,1 \%), \quad$ and oligoasthenoteratozoospermia $(6 ; 1.4 \%)$ were also common. The proportion of men who have these semen abnormalities were statistically significantly higher in the male HIV positive group $(25.8 \% ; 51)$ compared to the $16.3 \% ; 36)$ HIV negative group $(\mathrm{p}=0.022$; OR:1.7; $95 \%$ CI:1.1-2.8).

\section{Sperm quality and severity of HIV diseases among HIV positive patients}

The relationship between the semen quality and severity of HIV disease among the male HIV positive partners is shown in table 4 . The CD4 cell count levels were used as 
marker for severity of HIV disease. Semen parameters were compared between patients with CD4 counts level below and above 350 cells $/ \mathrm{mm}^{3}$. Of the five semen parameters (table 4) compared, HIV positive participants with more severe diseases (CD4 $<350$ cells $/ \mathrm{mm}^{3}$ ) had significantly lower mean sperm volume $(\mathrm{p}=0.003)$, sperm concentration $(\mathrm{p}=0.0002)$ and total sperm concentration $(\mathrm{p}<0.001)$ compared with HIV positive participants with less severe diseases (CD4 $>350$ cells $/ \mathrm{mm}^{3}$ ). No statistical significant difference were observed in mean \% normal morphology $(\mathrm{p}=0.34)$ and mobility $(\mathrm{p}=0.75)$.

Table 4: Relationship between CD4 cell count and semen parameters.

\begin{tabular}{|c|c|c|c|}
\hline $\begin{array}{l}\text { Semen } \\
\text { Parameters }\end{array}$ & $\begin{array}{l}\text { CD4 < } \\
350 \\
\text { cells } / \mathrm{mm}^{3}\end{array}$ & $\begin{array}{l}\mathrm{CD} 4 \geq 350 \\
\text { cells } / \mathrm{mm}^{3}\end{array}$ & $\begin{array}{l}\mathbf{P} \\
\text { value }\end{array}$ \\
\hline Mean volume (ml) & $2.6 \pm 1.3$ & $3.1 \pm 1.5$ & 0.003 \\
\hline $\begin{array}{l}\text { Sperm } \\
\text { concentration } \\
\left(10^{6}\right)\end{array}$ & $69.3 \pm 10.7$ & $84.7 \pm 6.7$ & 0.0002 \\
\hline $\begin{array}{l}\text { Total sperm } \\
\text { count }\left(10^{6} / \mathrm{ml}\right)\end{array}$ & $136.5 \pm 31.7$ & $237.1 \pm 47.9$ & $<0.001$ \\
\hline $\begin{array}{l}\text { Mean \% normal } \\
\text { Morphology }\end{array}$ & $64.9 \pm 15.3$ & $71.3 \pm 10.7$ & 0.34 \\
\hline Mean $\%$ mobility & $61.3 \pm 17.9$ & $64.7 \pm 12.4$ & 0.75 \\
\hline
\end{tabular}

Table 5: Bacterial Isolates from semen of male partners of HIV positive couple.

\begin{tabular}{|ll|}
\hline Organisms & Number $(\%)$ \\
\hline Staph aureus & $45(33.1)$ \\
Klebsiela & $27(19.9)$ \\
Candida albica & $23(16.9)$ \\
Proteus & $17(12.5)$ \\
Step feacali & $12(8.8)$ \\
Pseudomonas & $9(6.6)$ \\
\hline
\end{tabular}

\section{Microbial isolates from semen of patients}

Table 5 shows the microbial isolated from 123 (29.3\%) of the 419 semen samples. Although more organisms were isolated from the semen of the HIV positive samples (64; $32.3 \%$ ) compared to $26.7 \%$ (59) isolated from HIV negative samples, the difference was not statistically significant $(\mathrm{P}=0.21)$. More microorganisms were isolated in the normospermic samples than in the oligozoospermia samples $(31.1 \%$ vs. $27.0 \%)$, but the difference was not statistically significant $(\mathrm{P}=0.40)$. A total of 139 organisms were isolated from 123 infected specimens. In $16(13.0 \%)$ semen samples more than one organism was isolated. Staphylococcus aureus $(33.1 \%)$, E. coli (19.9\%) and Klebsiela (16.9\%) were the most common organism isolated from the semen samples.

\section{DISCUSSION}

Over thirty percent of the male partners of HIV positive couple seeking infertility care in our centre over the study period had abnormal semen quality $(31.7 \%)$. The quality of the semen of the HIV negative men were significantly better compared to HIV positive men. Among HIV positive men, those with severe disease tend to have lower quality semen. Approximately $22 \%$ of the semen of the men in this study was infected, with Staph aureus, E coli and Klebsiela being the most common microbial isolates.

The finding of over one third of the male partners of infertile couple having abnormal semen quality is similar to findings by other researchers in Ile Ife and Ibadan South Western Nigeria. ${ }^{8,9}$ It is however lower than rate reported by Ugwuja et al in Abakiliki in South Eastern Nigeria. ${ }^{10}$ Available but limited evidence shows that HIV positive women tend to have lower semen quality compared with HIV negative men. ${ }^{11}$ Looking at this gross comparison of prevalence of abnormal semen quality, it seems as if the assertion was not true. However comparing specific semen parameters, our study did detect significantly lower quality of semen in HIV positive men compared to HIV negative men. The later finding is similar to the findings of previous studies that addressed the effect of HIV infection on semen quality. ${ }^{11-}$

${ }^{13}$ In these studies several semen parameters were altered in the HIV positive population. The most obvious findings were the reduction in sperm morphology and mobility. Other observed abnormalities were in the volume, sperm concentration and total sperm count. It is important to also note that other studies have reported varying anomalies which vary from study to study. ${ }^{12,13}$ The obvious difference may therefore be attributable other factors other HIV, which may include methodologic variations, population studied, sample size and severity of HIV diseases. ${ }^{11,14,15}$

In this study, we also investigated the effect of the severity of HIV diseases measured by CD4 cell count and semen characteristics. HIV positive patients with CD4 cell count less than 350 cells $/ \mathrm{mm} 3$ have worse semen parameters of volumes, sperm concentration and total sperm count compared to those with CD4 count above 350 cells $/ \mathrm{mm}^{3}$. However no differences were noted in sperm morphology and mobility. The reported relationship between low CD4 count and some semen parameters is similar to findings by Politch et al and Dulioust et al. ${ }^{11,16}$ As currently there is no clear link between HIV infection and germ cell from available research findings, the effect observed may be due to specific behaviour of HIV positive individuals or concomitant occult infection. ${ }^{11}$

The findings in this study of approximately $32 \%$ of semen specimen being infected with microbial organisms is similar to findings in three previous studies. $8,17,18$ Infection of the male genital tract is an important cause of 
impairment of sperm function. It is also import to note that the isolated bacterial organisms may not be the cause of the low sperm quality but concomitant findings as result of compromised immunity due to HIV infection. The higher but microbial isolates from semen of HIV positive men compared to HIV negative men support this line of thought.

\section{CONCLUSION}

Male factor contributes about one third of infertility in this study and severity of HIV diseases impacts on semen quality. Further studies are needed to evaluate if antiretroviral therapy will reverse the effect of HIV infection on semen quality.

Funding: Nigerian Institute of medical Research Lagos Conflict of interest: None declared

Ethical approval: The study was approved by the Institutional Ethics Committee of Nigerian Institute of Medical Research Lagos who gave the ethical approval for the study and with the 1964 Helsinki declaration and its later amendments or comparable ethical standards.

\section{REFERENCES}

1. Lozano R, Naghavi M, Foreman K, Lim S, Shibuya $\mathrm{K}$, Aboyans V, et al. Global and regional mortality from 235 causes of death for 20 age groups in 1990 and 2010: a systematic analysis for the Global Burden of Disease Study 2010. Lancet. 2012;380:2095-128.

2. UNAIDS. 2012 progress reports submitted by countries. Geneva, Switzerland: UNAIDS; 2012.

3. Kushnir VA, Lewis W. Human immunodeficiency virus/acquired immunodeficiency syndrome and infertility: emerging problems in the era of highly active antiretrovirals. Fertility and sterility. 2011;96(3):546-53.

4. Loutfy MR, Hart TA, Mohammed SS, Su D, Ralph ED, Walmsley SL, Soje LC, Muchenje M, Rachlis AR, Smaill FM, Angel JB. Fertility desires and intentions of HIV-positive women of reproductive age in Ontario, Canada: a cross-sectional study. PloS one. 2009;4(12):e7925.

5. Ombelet W, Cooke I, Dyer S, Serour G, Devroey P. Infertility and the provision of infertility medical services in developing countries. Human Reproduction Update. 2008;14(6):605-21.

6. Okonofua FE. Infertility in sub-saharan Africa. Contemporary Obstetrics and Gynaecology for
Developing Countries. Women's Health and Action Research Centre. 2003:128-56.

7. WHO laboratory manual for the examination and processing of human semen. 5th ed. WHO Press, World Health Organization, 20 Avenue Appia, 1211 Geneva 27, Switzerland; 2010. pp. 7-113.

8. Owolabi AT, Fasubaa OB, Ogunniyi SO. Semen quality of male partners of infertile couples in Ile-Ife, Nigeria. Nigerian Journal of Clinical Practice. 2013;16(1):37-40.

9. Adeniji RA, Olayemi O, Okunlola MA, Aimakhu CO. Pattern of semen analysis of male partners of infertile couples at the University College Hospital, lbadan. West Afr J Med. 2003;22:243-5.

10. Ugwuja EI, Ugwu NC, Ejikeme BN. Prevalence of low sperm count and abnormal semen parameters in male partners of women consulting at infertility clinic in Abakaliki, Nigeria. Afr J Reprod Health. 2008;12:67-73.

11. Dulioust E, Le Du A, Costagliola D, Guibert J, Kunstmann JM, Heard I, et al. Semen alterations in HIV -1 Infected men. Human Reproduction 2002; 17(8):2112-8.

12. Crittenden JA, Hamdelsman DJ, Stewart GJ. Semen analysis in human immunodeficiency virus infection. Fertil steril. 1992;57:1294-9.

13. Dondero F, Tiziana R, D’Offizi G, Mazzili F, Rosso R, Sarandrea N. et al. Semen analysis in HIV seropositive men and in subjects at high risk for HIV infection. Human Reproduction. 1996;11:765-8.

14. Muller CH, Coomb RW, Kreger NJ. Effects of clinical stage and immunological status on semen analysis results in human immunodeficiency virus type 1 seropositive man. Andrologia. 1998;30(S1):15-22.

15. Lasheeb AS, Kinfg J, Ball JK, Cuman R, Barret CLR, Afnan M, et al. Semen characterisitcs in HIV-1 positive men and the effect of semen washing. Genitour Med. 1997;73:303-5.

16. Politch JA, Mayer KH, Abott AF, Anderson DJ. The effects of disease progression and Zidovudine therapy on semen quality in human immunodeficiency virus type 1 seropositive men. Fertil Sterli. 1994;61:922-8.

17. Ikechebelu JI, Adinma JI, Orie EF, Ikegwuonu SO. High prevalence of male infertility in Southeastern Nigeria. J Obstet Gynaecol. 2003;23:657-9.

18. Keck C, Gerber-Schafer C, Clad A, Wilhelm C, Breckwoldt M. Seminal tract infections: Impact on male fertility and treatment options. Hum Reprod Update. 1998;4:891-903.

Cite this article as: Ezechi OC, Wapmuk AE, Ohihoin AG, Ujah IAO. Semen quality of male partners of infertile couples living with HIV infection. Int J Reprod Contracept Obstet Gynecol 2016;5:1423-7. 